\title{
STRATEGI CITRA MEREK, KUALITAS PELAYANAN, DAN HARGA TERHADAP MINAT 66 MELANJUTKAN SEKOLAH
}

\author{
Abdul Mujid', Andrian² \\ Fakultas Ekonomi Universitas Bhayangkara Jakarta Raya ${ }^{1,2}$ \\ $\underline{\text { mujidog0998@gmail.com }}^{1}$; andrian@dsn.ubharajaya.ac.id ${ }^{2}$
}

\begin{abstract}
ABSTRAK
Penelitian ini bertujuan untuk mengatahui pengaruh Citra Merek, Kualitas Pelayanan, dan Harga terhadap Minat Melanjutkan Sekolah. Penelitian ini dilakukan dengan metode kuantitatif dan melakukan pengelolaan data mengunakan SPSS. Jumlah sampel 77 yang mengisi atau mengembalikan kuesioner dengan mengunakan metode sampling jenuh. Hasil dari penelitian menunjukan bahwa secara parsial citra merek terdapat pengaruh signifikan terhadap minat melanjutkan sekolah menengah kejuruan, kualitas pelayanan terdapat tidak pengaruh signifikan terhadap minat melanjutkan sekolah menengah kejuruan, harga terdapat pengaruh signifikan minat melanjutkan sekolah menengah kejuruan. Sedangkan dari hasil perhitungan statistic uji simultan menunjukan bahwa hipotesis diterima dengan kata lain citra merek, kualitas pelayanan dan harga secara simultan berpengaruh terhadap minat melanjutkan sekolah.
\end{abstract}

Kata kunci: Citra Merek, Kualitas Pelayanan, Harga, Minat

\section{Abstract}

This study aims to determine the effect of Brand Image, Service Quality, and Price on Interest in Continuing Study. This research was conducted with quantitative methods and data management using SPSS. The number of respondents were 77 who filled out or returned the questionnaire using the saturated sampling method. The results of the study show that partially brand image has a significant influence on interest in continuing vocational high school, service quality has no significant effect on interest in continuing vocational high school, price has a significant influence on interest in continuing vocational high school. Meanwhile, the results of the statistical calculation of the simultaneous test show that the hypothesis is accepted, in other words, brand image, service quality and price simultaneously affect the interest in continuing study.

Keywords: Transportation Brand Image, Service Quality, Price, Interest

\section{PENDAHULUAN}

Pada saat ini banyak masyarakat yang menyadari akan pentingnya pendidikan. Berdasarkan dari itu saat ini semakin banyaknya masyarakat akan kebutuhan peran jasa pendidikan maka dari itu jasa pendidikan untuk meningkatkan kualitas pendidikannya. Pendidikan sebagai komoditas ekonomi merupakan produk jasa yang dapat dipasarkan melalui strategi pemasaran jasa yang baik. Dengan pertumbuhan ekonomi yang pesat, menyebabkan semakin banyaknya masalah 
persaingan sekolah. Oleh karena itu, sekolah harus dituntut untuk menentukan bentuk persaingan yang dihadapinya dan memiliki strategi yang tepat untuk memasarkan layanan pendidikannya.

Banyak yang berangapan bahwa siswa SMP yang melanjutkan ke SMK adalah mereka yang kemampuan dasar relatif rendah dan kurang percaya diri bersaing di SMA yang menimbulkan persepsi bahwa masuk ke SMK bukan karena pilhan tapi karena keterpaksaan. Siswa/i SMP yang meneruskan ke SMK berpersepsi tidak akan bisa melanjutkan pendidikan yang lebih tinggi, tetapi untuk segera berharap untuk mendapatkan pekerjaan. Oleh karena itu citra sekolah dianggap menjadi variael yang berpengaruh terhadap minat siswa masuk SMK di Bekasi sebagaimana citra merk (brand image) mempengaruhi minat beli.

Era bisnis saat ini, tinginya tingkat persaingan telah membawa pengaruh yang signifikan dalam dunia usaha. Persaingan tidak hanya mengandalkan segi kualitas tetapi juga megutamakan segi pelayanan. Kosumen dapat memilih barang atau jasa yang akan mereka pergunakan,serta memiliki banyak kesempatan untuk membandingkan pilihan mereka,sehingga suatu organisasi atau perusahaan harus melakukan berbagai cara untuk mempertahankan eksistensinya ditengah masyarakat. Julukan pelanggan biasanya disebut adalah raja yang harus dilayani, tetapi ini tidak berarti bahwa semuanya diserahkan kepada pelanggan. Usaha memuaskan kebutuhan pelanggan harus dilakukan secara menguntungkan atau bersifat "winwin solution" yaitu dimaana kedua belah pihak merasa senang tidak ada yang dirugikan.

Kebutuhan pasar yang terus akan mengalami perkembangan maka tenaga kerja di tuntut agar mengikuti zaman pada eranya dalam hal ini Sekolah Menengah Kejuruan (SMK) sebagai salah satu bentuk peranan penting dalam mempersiapkan tenaga kerja. Sekolah di Indonesia masih kekurangan kesempatan untuk mendidik lulusan dengan dua skill (soft skill dan hard skill), yang pada akhirnya akan sulit bersaing di dunia kerja. Untuk menyiapkan tenaga kerja yang berkompeten sesuai harapan industri.

Dengan adanya SMK berarti Pemeritah memfasilitasi siswa yang maumengambil spesialisasi kejuruan dan siap masuk ke dunia kerja dan tidak menutup kemungkinan melanjutkan ke perguruan tinggi. Jika persepsi tidak berubah di masyarakat dan minat untuk tetap menerima SMK masih rendah, maka rencana pemerintah akan terhambat.

Tabel 1.1

Pendaftaran siswa/i baru 2018-2020

\begin{tabular}{|c|l|c|c|c|c|}
\hline \multirow{2}{*}{ NO } & \multirow{3}{*}{ PROGRAM KEAHLIAN } & \multicolumn{3}{|c|}{ TAHUN } & \multirow{2}{*}{ JUMLAH } \\
\cline { 3 - 5 } & & $2018 / 2019$ & $2019 / 2020$ & $2020 / 2021$ & \\
\hline 1 & Tenik audio visual & 21 & 26 & - & 47 \\
\hline 2 & Tenik kendaraa ringan & 105 & 169 & 102 & 376 \\
\hline 3 & Teknik instalasi tenaga listrik & 44 & 69 & 36 & 149 \\
\hline 4 & Multimedia & 66 & 105 & 71 & 242 \\
\hline \multicolumn{2}{|c|}{ Jumlah Seluruhnya } & 236 & 369 & 209 & 814 \\
\hline
\end{tabular}

Sumber: SMK Karya Guna 1 Bekasi

Berdasarkan tabel diatas dapat dilihat terjadi penurunan pendaftaran siswa/i di tahun ajaran 2019/2020 kurangnya strategi pemasaran dalam citra merk. Selain citra sekolah, kualitas pelayanan, dan harga dinggap mempengaruhi minat siswa . Seseorang mempunyai minat memutuskan untuk masuk pada sekolah tertentu karena adanya upaya menarik/penawaran oleh pihak sekolah yang di samakan dengan promosi dan iklan. Citra sekolah yang akan dimasuki oleh siswa yang disamakan dengan brand image (citra merk),pertimbangan biaya pendidikan yang disamakan dengan harga (price) (Karyati, 2016). 
Apabila rencana penambahan jumlah SMK tersebut terealisasi dan siswa SMP kurang berminat untuk terus melanjutkan ke SMK, tentunya akan menghambat realisasi tujuan yang telah ditetapkan oleh pemerintah melalui kebijakan ini.. Sekolah sebagai produsen jasa pedidikan sama dengan aktivitas ekonomi secara teoritis menimbulkan konsep biaya yang sama sehingga memunculkan harga (biaya pendidikan) sebagaimana minat beli dipengaruhi oleh harga sama halnya minat siswa dipengaruhi biaya pendidikan.

Penelitian ini dilakukan pada SMK Karya Guna 1 Bekasi dengan subyek penelitiannya adalah para siswa/siswi di SMK Karya Guna 1 Bekasi. Penelitian ini dilakukan untuk mengetahui bahwa pentingnya Strategi Citra Merek, Kualitas Pelayan dan Harga mempengaruhi minat melanjutkan Sekolah, dikarenakan saat ini layanan jasa pendidikan adalah sebagai kebutuhan.

Hal ini menjadi pertimbangan penulis mengapa Strategi Citra Merek, Kualitas Pelayan dan Harga mempengaruhi minat melanjutkan Sekolah. Untuk itu penulis memutuskan untuk melakukan penelitian dengan judul "Strategi Citra Merek Kualitas Pelayanan dan Harga Terhadap Minat melanjutkan Sekolah".

\section{KAJIAN TEORETIK}

\section{Citra Merek}

Banyaknya bermacam-macam merek di pasar akan memberikan alternatif pilihan kepada konsumen dalam melakukan pembelian. Konsumen yang membeli produk tidak hanya akan melihat produk dari segi kualitas produk, tetapi juga melihat citra merek pada produk tersebut. Citra merek melibatkan reputasi dan kredibilitas suatu produk, yang kemudian digunakan sebagai pedoman bagi konsumen untuk mencoba dan mengonsumsi produk atau layanan tertentu.

Menurut Kotler dan Keller (2016 : 330) menyatakan bahwa "Citra merek menggambarkan sifat ekstrinsik produk atau layanan, termasuk cara merek berusaha memenuhi kebutuhan psikologis atau sosial pelanggan". Berbeda halnya dengan Fachrizal (2018) menyatakan bahwa "Citra merek adalah persepsi tentang brand yang merupakan refleksi memori konsumen akan asosiasinya pada merek tersebut”.

Berdasarkan beberapa pendapat diatas maka dapat disimpulkan bahwa citra merek merupakan sebuah persepsi dibenak konsumen ketika mengingat sebuah merek tertentu pada suatu produk ataupun jasa.

\section{Indikator Citra Merek}

Adapun indikator brand image menurut Anggi (2016),yaitu, terdiri dari :

1. Persepsi konsumen terhadap perusahaan yang membuat barang atau jasa

2. Persepsi konsumen terhadap pemakai atau pengguna barang atau jasa tersebut termasuk pemakai itu sendiri, gaya hidup dan status social.

3. Persepsi konsumen terhadap produk meliputi atribut, manfaat, penggunaanya serta jaminan yang diberikan produk.

4. Persepsi konsumen terhadap selebriti pendukung iklan produk tersebut.

\section{Kualitas Pelayanan}

Pelanggan biasanya mengharapkan untuk menerima atau menikmati produk berupa barang atau jasa yang mereka konsumsi dengan pelayanan yang baik atau 
memuaskan. Dengan kata lain, pelanggan menginginkan kualitas layanan yang sesuai dengan harapannya. Dalam hal ini, perusahaan pasti akan berusaha memberikan pelayanan atau service yang baik (quality of service) kepada pelanggan. Ini merupakan upaya perusahaan untuk membuatnya berbeda dari para pesaingnya.

Kualitas jasa atau kualitas pelayanan yang mendefinisikan sebagai kondisi dinamis yang berhubungan dengan produk, jasa, sumber daya manusia, proses dan lingkungan yang memenuhi atau melebihi harapan (Endang Rusdianti, Paulus Wardoyo, 2018). Kualitas layanan diartikan sebagai perilaku atau perilaku individu atau organisasi yang bertujuan untuk memuaskan pelanggan atau karyawan. (Drs.Daryanto \& Drs. Ismanto Setyabudi, 2014).

Ketika pelayanan yang dirasakan atau diterima sesuai dengan yang diharapkan, maka kualitas pelayanan dapat di apresiasikan baik dan memuaskan. Tetapi ketika pelayanan yang dirasakan atau diterima melampaui harapan pelanggan, maka kualitas pelayanan di apresiasikan sebagai kuaitas pelayanan yang ideal. Dan begitu sebaliknya ketika yang di rasakan atau diterima lebih rendah maka kualitas pelayanan dianggap kurang baik. Kualitas harus dapat memenuhi kinginan pelanggan agar dapat diapresiasi dengan baik dan memuaskan. Instansi pemerintah dan swasta senantiasa berusaha semaksimal mungkin untuk memberikan kualitas pelayanan prima yang terbaik kepada konsumen tetap dan tidak tetap seperti sikap dan perilaku serta sopan santun berbicara antara customer service dengan konsumen (Soehardi, 2021) (Murdayani et al., 2021).

Menurut Kotler dalam (Jufriyanto, 2020), secara garis besar karakteristik jasa terdiri 5 (lima) dimensi kualitas pelayanan yang masuk kedalam indikator kualitas pelayanan, antara lain :

1. Keandalan (eliability)

2. Daya Tanggap (responsiveness)

3. Jaminan (asurance)

4. Bukti fisik (tangible)

5. Empati (emphaty)

\section{Harga}

Harga merupakan satu-satunya elemen dalam bauran pemasaran yang dapat menghasilkan pendapatan bagi perusahaan. Harganya fleksibel dan bisa berubah sewaktu-waktu. Harga adalah label pada produk yang harus dibayar untuk mendapatkan produk / jasa tersebut. Harga merupakan faktor yang berpengaruh besar terhadap keputusan pembelian. Pelanggan biasanya membandingkan harga produk sebelum membeli.

(Fandy Tjipono, 2016), Menyatakan bahwa harga adalah unsur penting dalam sebuah perusahaan dimana dengan adaya harga maka perusahaan akan mendapatkan income bagi keberlangsungan perusahaan. Selain itu, harga juga menjadi alat yang akan digunakan sebagai proses bagi pelanggan untuk menukar barang atau jasa.

Menurut Tjipono dalam (Muharam \& Soliha, 2018) persepsi harga dapat diukur melalui beberapa indikator yang terdiri dari:

1. Kesesuaian harga dengan kualitas produk.

2. Kesesuaian harga dengan manfaat.

3. Harga bersaing.

\section{Minat}

(Defriyanto \& Purnamasari, 2016) menyatakan bahwa minat adalah kecendrungan jiwa kearah sesuatu karena sesuatu itu mengandung arti bagi kita, 
sesuatu itu memenuhi kebutuhan dan dapat menyenangkan kita, jadi minat bukanlah kecendrungan yang dipaksa. Dari pernyataan diatas dapat disimpulkan bahwa minat merupakan keinginan melakukan sesuatu tanpa paksaan yang menurutnya ada manfaat bagi dirinya, menyenangkan dan dapat memenuhi segala kebutuhannya

(Andrian, 2019) Minat adalah hal-hal pribadi yang berhubungan dengan sikap, individu yang tertarik pada suatu objek akan memiliki kemampuan atau motivasi untuk melakukan serangkaian tindakan untuk mendekati atau memperoleh objek tersebut. Minat beli adalah keinginan untuk membeli suatu produk atau jasa karena pengaruh eksternal dan internal, terlebih dahulu produk atau jasa yang akan dibeli telah dievaluasi. Semakin kuat atau semakin dekat hubungan tersebut, maka akan semakin besar minat yang dirasakannya. Minat dapat timbul karena daya tarik dari luar dan juga datang dari lubuk hati seseorang. Berdasarkan pendapat dari beberapa ahli dapat disimpulkan bahwa minat merupakan suatu kecenderungan rasa lebih suka dan ketertarikan seseorang terhadap suatu kegiatan yang menimbulkan perasaan senang.

Menurut Susanti, 2017 minat beli dapat diidentifikasi melalui indikatorindikator sebagai berikut :

1. Minat transaksional, yaitu kecenderurang individu untuk membeli suatu produk.

2. Minat refrensial, kecenderungan individu untuk merekomendasikan produk kepada orang lain.

3. Minat preferensial, yaitu kepentingan yang menunjukkan perilaku pribadi yang menjadikan produk sebagai pilihan utama. Opsi utama ini hanya dapat diganti jika produk gagal.
4. Minat eksploratif, yaitu artinya perilaku individu yang selalu mencari informasi tentang produk yang diminati untuk mendukung fitur-fitur positif yang ada pada produk tersebut.

\section{METODE PENELITIAN}

Text Dalam penelitian ini penulis menggunakan metode kuantitatif. Menurut (Rikziana \& Kartini, 2017) menyatakan bahwa "pendekatan kuantitatif adalah pengukuran data kuantitatif dan statistik objektif melalui perhitungan ilmiah berasal dari sampel orang-orang atau penduduk yang diminta menjawab atas sejumlah pertanyaan tentang survey untuk menentukan frekuensi dan prosentase tanggapan mereka”.

Dalam penelitian ini skala yang akan digunakan untuk pengukuran variable adalah bentuk skala likert. Skala likert dalam (Irwan \& Adam, 2015) berfungsi untuk mengukur sikap, pendapat dan persepsi seseorang/kelompok orang tentang fenomena sosial.

Dalam pelaksanaan penelitian ini, lokasi penelitiannya adalah SMK Karya Guna 1 Bekasi yang beralamat Komplek Perumahan Duren Jaya, Jl. Cirebon, Duren Jaya, Bekasi Timur, RT.002/RW.001, Duren Jaya, Kec. Bekasi Tim., Kota Bks, Jawa Barat 17111.

Populasi adalah suatu wilayah yang tergeneralisasi, terdiri dari objek atau topik dengan kualitas dan karakteristik tertentu yang ditentukan oleh peneliti untuk dipelajari dan diambil kesimpulannya. (Sugiyono, 2017). Pada penelitian ini adalah populasi berjumlah 143 yang membeli/mengambil formulir pada periode bulan April 2021 dan yang 
mengisi/mengembalikan sebanyak 77 kuesioner.

\section{HASIL PENELITIAN PEMBAHASAN}

\section{Uji Validitas}

Uji validitas digunakan untuk mengukur tingkat validitas suatu kuesioner. Uji validitas dilakukan dengan menggunakan metode analisis korelasi. Berdasarkan nilai sig. < 0,05 valid, jika nilai sig. > 0,05 tidak valid. Berikut hasil uji validitas yang telah dilakukan dapat dilihat pada tabel-tabel berikut :

Tabel 1.

Hasil Uji Validitas

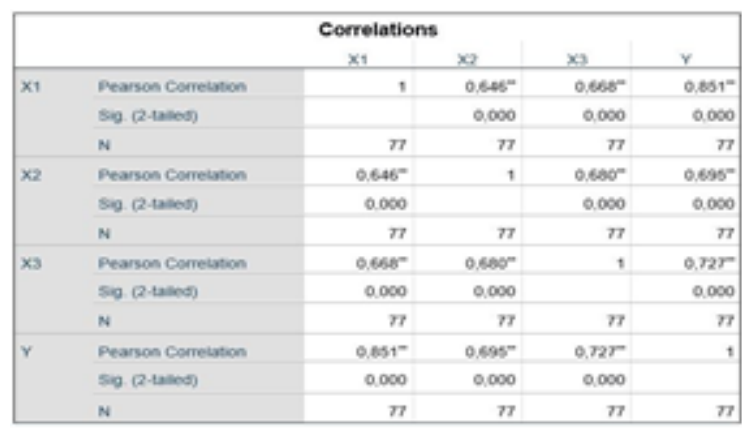

Sumber : data diperoleh dari SPSS versi 25 (2021)

Dari tabel tersebut dapat diketahui bahwa nilai dari semua indikator menunjukan nilai sig. $0,000<0,05$ sehingga dapat disimpulkan bahwa masingmasing indikator adalah valid. Sehingga semua item pernyataan dapat digunakan untuk alat ukur citra merek, kualitas pelayanan, harga terhadap minat.

\section{Uji Reliabilitas}

Uji reliabilitas ini dilakukan kepada pengisi kuesioner yang bertotal 77 responden yang disebarkan kepada siswa/i SMP pembeli formulir pada sekolah SMK
Karya Guna 1 Bekasi. dikatakan reliabel jika memberikan nilai cronbach alpha $>0,6$.

Tabel 2.

Hasil Uji Reliabilitas

\begin{tabular}{|r|r|}
\hline \multicolumn{3}{|c|}{$\begin{array}{c}\text { Reliability Statistics } \\
\text { Cronbach's Alpha } \\
\text { Based on } \\
\text { Cronbach's Alpha }\end{array}$} & Standardized Items & N of Items \\
\hline 0,906 & 0,908 \\
\hline
\end{tabular}

Sumber : data diperoleh dari SPSS versi 25 (2021)

Dari tabel diatas dapat diketahui bahwa hasil nilai cronboach alpha 0,906 lebih besar dari o,6. Sehingga item pernyataan pada angket reliabel dan dapat digunakan untuk alat ukur persepsi citra merek, kualitas pelayanan, dan harga terhadap minat melanjutkan sekolah menengah kejuruan.

\section{Uji Normalitas}

Uji normalitas digunakan untuk melihat apakah nilai residual terdistribusi normal atau tidak. Jadi, uji normalitas bukan dilakukan pada masing-masing variabel tapi pada nilai residualnya. Untuk mendeteksinya normalitas data dapat juga dengan uji Kolmogrof - Smirnov dilihat dari nilai residual. Dikatakan normal bila nilai residual yang dihasilkan di atas nilai signifikan yang ditetapkan. Kriteria pengujiannya adalah sebagai berikut :

1. Jika nilai signifikasi (asymp sig 2 tailed) $>0,05$, maka data berdistribusi normal.

2. Jika nilai signifikasi (asymp sig 2 tailed) $<$ 0,05, maka data berdistribusi tidak normal. 
Tabel 3 .

Hasil Uji Normalitas



Sumber : data diperoleh dari SPSS versi 25 (2021)

Berdasarkan tabel tersebut diketahui bahwa nilai signifikasi asymp. Sig (2 tailed) sebesar 0,083 lebih besar dari 0,05. Maka sesuai dengan dasar pengambilan keputusan dalam uji normalitas Kolmogrof - Smirnov diatas, dapat disimpulkan bahwa data berdistribusi normal.

\section{Uji Multikolinearitas}

Uji multikolinearitas dalam penelitian ini dilakukan untuk menguji apakah model regresi ditemukan adanya korelasi antar variabel bebas (independent), karena model regresi yang baik seharusnya tidak terjadi korelasi yang kuat diantara variabel independen. Multikolinearitas dapat dilihat dari nilai tolerance dan VIF (Variance Inflation Factor). Tidak terjadi Multikolinearitas apabila nilai tolerance $\geq$ 0,10 atau $\mathrm{VIF} \leq 10$.

Dari tabel tersebut dapat diketahui bahwa nilai Tolerance atau nilai VIFnya dari semua indikator menunjukan semua variabel bebas tidak terjadi multikolinearitas.
Tabel 4.

Hasil Uji Multikolinieritas

\begin{tabular}{|r|r|}
\hline \multicolumn{2}{|c|}{ Collinearity Statistics } \\
\hline Tolerance & VIF \\
\hline & \\
\hline 0,485 & 2,063 \\
\hline 0,471 & 2,124 \\
\hline 0,447 & 2,235 \\
\hline
\end{tabular}

Sumber : data diperoleh dari SPSS versi 25 (2021)

\section{Uji Heterokedastisitas}

Uji heterokedastisitas ini digunakan untuk menguji apakah dalam model regresi terjadi ketidaksamaan varian dari residual satu pengamatan ke pengamatan yang lain. Jika varian dari residual satu pengamatan ke pengamatan lain tetap, maka disebut homoskedastisitas dan jika berbeda disebut hetoroskedasitas. Model regresi yang baik adalah homoskedasitas atau tidak terjadi hetoreskedasitas dapat dilihat dari grafik scatterplot antara nilai prediksi variabel terikat (dependen) yaitu ZPRED dengan residualnya SRESID mendeteksi ada tidaknya heteroskedasitas dapat dilakukan dengan melihat ada tidaknya pola tertentu pada grafik scatterplot antara SRESID dan ZPRED dimana sumbu Y adalah Yyang telah di prediksi dan sumbu $X$ adalah residual $(Y$ prediksi - Y sesungguhnya) yang telah distudentized.



Sumber : data diperoleh dari SPSS versi 25 (2021) 
Berdasarkan grafik scatterplot diatas dapat diketahui tidak terjadi hetoreskedasitas karena tidak ada tidaknya pola tertentu pada grafik scatterplot.

\section{Analisa Regresi Linear Berganda}

Regresi linier adalah metode statistika yang digunakan untuk membentuk model hubungan antara variabel terikat $(\mathrm{Y})$ dengan satu atau lebih variabel bebas (X1, X2 dan $\mathrm{X}_{3}$ ). Penggunaan Regresi linier berganda dalam penelitian ini bertujuan untuk mendeskripsikan dan memprediksi bagaimanakah citra merek, kualitas pelayanan dan harga terhadap minat dengan menggunakan observational data dari hasil penyebaran kuisioner. Hasil perhitungan regresi linier berganda dalam penelitian ini akan menghasilkan jawaban atas pernyataan hipotesis dan melihat besarnya nilai pengaruh seluruh variabel bebas terhadap variabel terikat.

Tabel 5 .

Hasil Uji Analisis Linier Berganda

\begin{tabular}{|c|c|c|c|}
\hline \multicolumn{2}{|r|}{ Model } & \multicolumn{2}{|c|}{ Unstandardized Coefficients } \\
\hline & & B & Std. Error \\
\hline \multirow[t]{4}{*}{1} & (Constant) & 3,431 & 1,105 \\
\hline & Citra Merek & 0,518 & 0,067 \\
\hline & Kualitas Pelayanan & 0,145 & 0,074 \\
\hline & Harga & 0,192 & 0,073 \\
\hline
\end{tabular}

Sumber : data diperoleh dari SPSS versi 25 (2021)

Berdasarkan tabel di atas maka dapat diperoleh model persamaan regresi linier berganda sebagai berikut:

$Y=3,431+0,518 X 1+0,145 X 2+0,192$ $\mathrm{X}_{3}+\mathbf{e}$

\section{Uji t (Parsial)}

Uji $\mathrm{t}$ untuk mengetahui pengaruh variabel bebas citra merek, kualitas pelayanan dan harga terhadap variabel terikat yaitu minat melanjutkan sekolah menengah kejuruan maka perlu dilakukan uji t. Pengujian secara parsial dapat dilihat dari uji t. Apabila nilai probabilitasnya lebih kecil dari 0,05 maka Ho ditolak yang berarti ada pengaruh yang signifikan.

Tabel 6. Hasil Uji t Parsial

\begin{tabular}{|l|r|}
\hline \multicolumn{1}{|c|}{$\mathrm{t}}$. & \multicolumn{1}{c|}{ Sig. } \\
\hline 3,106 & 0,003 \\
\hline 7,707 & 0,000 \\
\hline 1,967 & 0,053 \\
\hline 2,640 & 0,010 \\
\hline
\end{tabular}

Sumber : data diperoleh dari SPSS versi 25 (2021)

Berdasarkan tabel di atas menunjukkan hasil uji t (parsial) yang akan dijelaskan sebagai berikut :

1. Citra merek (X1) terhadap minat (Y) dengan nilai thitung citra merek (X1) sebesar 7,707 > t tabel 1,992 didukung dengan nilai sig. sebesar 0,003 yang lebih kecil dari 0,05 (5\%) maka Ho ditolak dan Ha diterima, sehingga dapat dikatakan variabel citra merek (X1) mempunyai pengaruh signifikan terhadap minat $(\mathrm{Y})$.

2. Kualitas pelayanan (X2) terhadap minat (Y) dengan nilai thitung kualitas pelayanan (X2) sebesar $1,967<\mathrm{t}$ tabel 1,992 didukung dengan nilai sig. sebesar 0,053 yang lebih besar dari 0,05 (5\%) maka Ho diterima dan $\mathrm{Ha}$ ditolak, sehingga dapat dikatakan variabel kualitas pelayanan (X2) tidak pengaruh signifikan terhadap minat (Y).

3. Harga $\left(\mathrm{X}_{3}\right)$ terhadap minat $(\mathrm{Y})$ dengan nilai thitung harga $\left(\mathrm{X}_{3}\right)$ sebesar 2,640 > $\mathrm{t}$ tabel 1,992 didukung dengan nilai sig. sebesar 0,010 yang lebih kecil dari 0,05 (5\%) maka Ho ditolak dan Ha diterima, sehingga dapat dikatakan variabel harga 
(X3) mempunyai pengaruh signifikan terhadap minat $(\mathrm{Y})$.

\section{Uji F (Simultan)}

Uji $F$ (simultan) digunakan untuk mengetahui pengaruh dari variabel kualitas pelayanan, harga dan fasilitas terhadap variabel kepuasan konsumen secara bersama sama (simultan). Hasil uji F dapat dilihat pada tabel dibawah ini, jika nilai probabilitas lebuh kecil dari o,5 maka $\mathrm{H} 1$ diterima dan menolak Ho, sedangkan jika nilai probabilitas lebih besar dari o,5 maka Ho diterima dan menolak H1.

Tabel 7.

Hasil Uji F simultan

\begin{tabular}{|c|c|}
\hline $\mathrm{F}$ & Sig. \\
\hline 87,056 & $0,000^{\mathrm{b}}$ \\
\hline
\end{tabular}

Sumber : data diperoleh dari SPSS versi 25 (2021)

Dari perhitungan statistik tabel di atas menunjukkan nilai $\mathrm{F}$ hitung $=87.056>$ F tabel $=2,73$ dan nilai signifikansi $0,000<$ 0,05, hal ini menunjukkan bahwa citra merek, kualitas pelayanan, dan harga mempengaruhi secara simultan dan signifikan terhadap variabel minat sekolah menengah kejuruan.

\section{Uji Koefisien Determinasi ( $\left.\mathbf{R}^{2}\right)$}

Pengujian pengaruh variabel independen yaitu citra merek, kualitas pelayanan, dan harga terhadap variabel dependen yaitu minat menghasilkan $\mathrm{R}^{2}$ (koefisien determinasi) sebagai berikut:

Berdasarkan tabel di bawah ini terlihat bahwa koefisien determinasi yang diperoleh sebesar 0,773 atau dengan kata lain variabel citra merek, kualitas pelayan dan harga memiliki berpengaruh secara signifikan terhadap variabel minat melanjutkan sekolah menengah kejuruan sebesar $77,3 \%$, sedangkan sisanya $22,7 \%$ dipengaruhi oleh variabel lain di luar model regresi ini.

Tabel 8.

Hasil Uji Kefisien Determinasi ( $\left.{ }^{2}\right)$

\begin{tabular}{|lc|r|r|r|}
\hline \multicolumn{7}{|c|}{ Model Summary } \\
Model & $\mathrm{R}$ & $\begin{array}{c}\mathrm{R} \\
\text { Square }\end{array}$ & \multicolumn{1}{c|}{$\begin{array}{c}\text { Adjusted } \mathrm{R} \\
\text { Square }\end{array}$} & $\begin{array}{r}\text { Std. Error of } \\
\text { the Estimate }\end{array}$ \\
\hline 1 & $0,884^{\mathrm{s}}$ & 0,782 & 0,773 & 1,16742 \\
\hline
\end{tabular}

Sumber : data diperoleh dari SPSS versi 25 (2021)

Berdasarkan tabel di atas terlihat bahwa koefisien determinasi yang diperoleh sebesar 0,773 atau dengan kata lain variabel citra merek, kualitas pelayan dan harga memiliki berpengaruh secara signifikan terhadap variabel minat melanjutkan sekolah menengah kejuruan sebesar 77,3\%, sedangkan sisanya 22,7\% dipengaruhi oleh variabel lain di luar model regresi ini.

\section{KESIMPULAN}

Text Berdasarkan pada hasil analisis dan penelitian yang telah dilakukan maka dapat disimpulkan sebagai berikut :

1. Variabel citra merek mempunyai pengaruh signifikan terhadap minat melanjutkan ke SMK Karya Guna 1 Bekasi.

2. Variabel kualitas pelayanan tidak pengaruh signifikan terhadap minat melanjutkan ke SMK Karya Guna 1 Bekasi

3. Variabel harga mempunyai pengaruh signifikan terhadap minat melanjutkan SMK Karya Guna 1 Bekasi

4. Citra merek, kualitas pelayanan, dan harga secara simultan berpengaruh terhadap minat melanjutkan ke SMK Karya Guna 1 Bekasi

\section{IMPLIKASI DAN MANAJERIAL}

Berdasarkan hasil penelitian dan kesimpulan yang diperoleh dari penelitian 
ini, implikasi manajerial yang di tuangkan yaitu sekolah harus terus memperhatikan harga yang ditawarkan agar siswa/i SMP yang akan masuk SMK yang ditawarkan bisa terjangkau oleh orang tua atau wali siswa/i SMP dalam upaya menciptkan minat melanjutkan sekolah menengah kejuruan dikarenakan persaingan semakin ketat dimana sekolah menawarkan harga terjangkau. sekolah juga terus mempertahankan citra merek yang sudah baik dan terus melakukan hal-hal yang baik dalam kualitas pelayanan maupun kegiatan lainnya untuk meningkatkan citra merek sekolah yang positif dan dapat dipercaya.

Variabel citra merek, kualitas pelayan dan harga memiliki berpengaruh secara signifikan terhadap variabel minat melanjutkan sekolah menengah kejuruan sebesar $77,3 \%$, sedangkan sisanya $22,7 \%$ dipengaruhi oleh variabel lain di luar model regresi ini.

\section{DAFTAR PUSTAKA}

Andrian. (2019). Digital Marketing dan Ragam Produk pada Minat Beli Konsumen Toko Online Shopee (Studi Kasus pada Mahasiswa Prodi Manajemen Fakultas Ekonomi Universitas Bhayangkara Jakarta Raya Angkatan 2016). Ekspektra: Jurnal Bisnis Dan Manajemen, 3(1), 14. https://doi.org/10.25139/ekt.v3i1.143 o

Defriyanto, \& Purnamasari, N. (2016). Pelaksanaan Layanan Bimbingan Konseling Karir dalam Meningkatkan Minat Siswa dalam Melanjutkan Studi Kelas XII di SMA Yadika Natar. KONSELI: Jurnal Bimbingan Dan Konseling (E-Journal), 3(2), 206-220.

Drs.Daryanto, \& Drs. Ismanto Setyabudi, M. P. (2014). Konsumen dan Pelayanan Prima (D. Bintoro (ed.)). GAVA MEDIA.
Endang Rusdianti, Paulus Wardoyo, S. P. (2018). STUDI TENTANG KEPUTUSAN SISWA MELANJUTKAN STUDI DI SEKOLAH MENENGAH KEJURUAN (SMK) KABUPATEN SEMARANG. Journal of Chemical Information and Modeling, 53(9), 1689-1699.

Fachrizal. (2018). PENGARUH KUALITAS PRODUK DAN CITRA MEREK TERHADAP PROSES KEPUTUSAN PEMBELIAN SMARTPHONE XIAOMI (Survei Pada Mahasiswa Fakultas Ekonomi dan Bisnis Universitas Pasundan Bandung). 38.

Fandy Tjipono. (2016). Pengaruh Kualitas Pelayanan, Harga Terhadap Kepuasan Pelanggan. Journal of Chemical Information and Modeling, 9(1), 1853 .

Ii, B. A. B., \& Merek, A. C. (2016). Pengaruh Citra Merek..., Anggi Julia Wijayanti, Fakultas Ekonomi Dan Bisnis UMP, 2018. 2014, 25-36.

Irwan, \& Adam, K. (2015). Metode Partial Least Square (PLS) Dan Terapannya (Studi Kasus: Analisis Kepuasan Pelanggan terhadap Layanan PDAM Unit Camming Kab. Bone). Teknosains, 9(1), 53-68.

Jufriyanto, M. (2020). Analisis Tingkat Kepuasan Konsumen Pada Kualitas Pelayanan Kedai Kopi Shelter. Matrik, 2O(2), https://doi.org/10.30587/matrik.v20i 2.1131

Karyati. (2016). Pengaruh Citra Merek (Brand Image) dan Persepsi Biaya Pendidikan Terhadap Minat Melanjutkan Studi Pada Prodi Pendidikan Akuntansi FE UNY (Studi Kasus Pada Siswa Kelas XII IPS/IIS SMA Negeri Di Gunungkidul Tahun Ajaran 2015/2016). Skripsi.

Kottler, \& Keller. (2016). Marketing Managemen (S. Wall (ed.); 15e ed.). Global Edition. 
Muharam, W., \& Soliha, E. (2018). Kualitas Produk, Citra Merek, Persepsi Harga Dan Keputusan Pembelian Konsumen Honda Mobilio. Ilmu Dan Riset Manajemen, 7(2014), 1-15.

Murdayani, M., Nurbaiti, B., \& Soehardi, S. (2021). The Effect of the Marketing Mix of MSME Products on Sales Volume During the Covid-19 Pandemic The Effect of the Marketing Mix of MSME Products on Sales Volume During the Covid-19 Pandemic. Journal of Strategic and Global Studies, 4(2), 2740.

https://doi.org/https://doi.org/https:/ /doi.org/10.7454/jsgs.v4i2.1043

Rikziana, Y. P., \& Kartini. (2017). Analisis Tingkat Financial Literacy dan Financial Behavior Mahasiswa S-1 Fakultas Ekonomi Universitas Islam Indonesia. Efektif Journal Ekonomi Dan Bisnis, 7(1), 76-99.

Soehardi, S. (2021). Model Peningkatan Volume Penjualan Melalui Kualitas Produk, Kualitas Pelayanan Dan Loyalitas Kopi Golda. Jurnal Manajemen Strategi Dan Aplikasi Bisnis, 4(2), 353-360. https://doi.org/http://ejournal.imperi uminstitute.org/index.php/JMSAB/art icle/view/398

Susanti, D. (2017). Pengaruh Kualitas Produk Terhadap Minat Konsumen Dalam Membeli Produk Tupperware Pada Perumahan Griya Tika Utama Pekanbaru. Menara Ekonomi, 3(5), 23-32. 